\title{
MEASUREMENT OF CARBON MONOXIDE EMISSIONS FROM VEHICLES EXHAUST PIPE USING PORTABLE GAS DETECTOR
}

\author{
H.A.Hassoon \\ Lecturer
}

Department. Biology.College. Science. University of Baghdad, Baghdad, Iraq hassanainabbood@yahoo.com

\section{ABSTRACT}

Carbon monoxide $(\mathrm{CO})$ contamination represents a major global concern. This study aimed to detect the concentration of $\mathrm{CO}$, emitted from various vehicles exhausters which are important contributors in deteriorating air quality. The data was collected throughout the heavy parking period at Al- Jadyria campus in Baghdad University. The vehicles were classified into two main groups according to the type of gasoline they are filled with; including premium leaded and leaded free gasoline (PLG and LFG respectively), as well as engine size, odometer, brand and model. Seven low duty vehicles for each engine size $(<1.6$ to $>2.0)$ liter were selected randomly. A portable gas detector type (Altair ${ }^{\circledR} 4 \mathrm{X}$ ) was used to measure exhausted emission of $\mathrm{CO}$ during idle mode. The results showed that high mean levels of CO (206.111-939) ppm were observed within vehicles filled with PLG. In contrast, the vehicles filled with LFG had been detected with an observable decline (9.5714-21.5714) ppm. Also, a significant difference in gas concentration between fuel types was observed within various engine groups. This study recommended controlling these emissions and raising the concern of the government about the gasoline quality due to their adverse impact on human health and environment.

Keywords: Air quality, noxious gases, gasoline type.

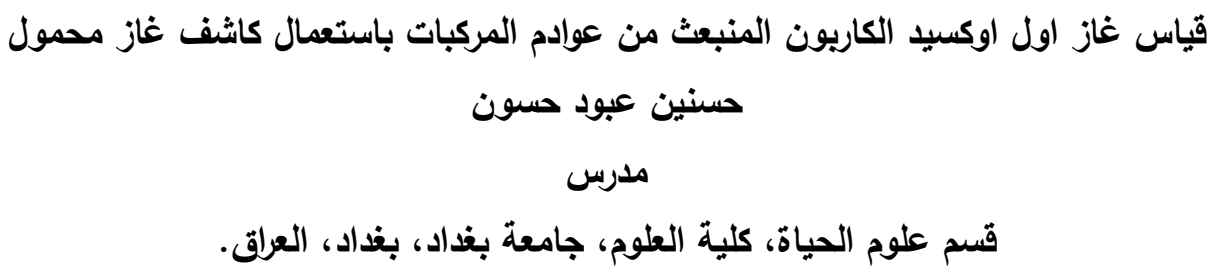

يمثل التلوث بغاز اول اوكسيد الكاريون مصدر قلث على مستوى عالمي. هدفت هذه الدراسه الى الكشف عن تركيز غاز اول اوكسيد الكابون المنبعث من عوادم المركبات المختلفه و التي باتت تثكل المساهم الاهم في تدهور نوعية الهواء. جمعت البيانات خلال فترة الأروه للساحات المخصصه للوقوف ضمن المجمع العلمي لجامعة بغداد الكائن في منطقة الجادريه. صنفت المركبات الى مجموعتين رئيسيتين طبقا لتوع الوقود (الغازولين) المعبئه به و الأي تضمن الوقود الحاوي و الخالي من الرصاص ـ فضلا عن حجم المحرك و عداد المسافات و الماركه و سنة الصنع. اختيرت سبعة سيارات بشكل عثوائي لكل فئة محرك و التي تراوحت بين اقل من 1.6 و الى اعلى من 2.0 لتر, تم استخدام جهاز محمول كاثف للغازات لقياس الانبعاثات من عوادم المركبات في حالتها الخامله. بينت النتائج ان اعلى مستوى لمتوسط تركيز الغاز و الذي تراوح ما بين (206.111-939) جزء بالمليون كان ضمن المركبات المعبئه بالوقود الحاوي على الرصاص, في حين اظهرت تلك المعبئه بالوقود الخالي من الرصاص انخفاضا ملحوضا في المتوسطتراوح ما بين (21.5714-9.5714) جزء بالمليون. كذلك فان فروق معنويه في تركيز الغاز قد ظهرت بين نوعي الوقود ضمن فئات المحركات المختلفه. ان هذه الدراسه تقترح السيطره على هذه الانبعاثات و زيادة الوعي الحكومي تجاه نوعية الوقود نتيجة لتأثيره السلبي على صحة الانسان و البيئه. الكلمات المفتاحيه: نوعية الهواء, الغازات الضاره, انواع وقود الغازولين. 


\section{INTRODUCTION}

The concept of air quality is becoming a common concern in the society. Environmental pollution, particularly its aerial component, is one of the top problems which should be taken more seriously. Its harmful effect on human health and require a quite understanding than those of any other pollutants (21). Controlling of these pollutants represented a valuable step to reduce the levels of noxious gases in the atmosphere (5). Vehicle exhaust emissions are considered as the main source that rising gas levels especially in large urban cities with high traffic congestion (21).Emissions from internal combustion (IC) engine are responsible for about $70 \%$ of the most undesirable gases such as carbon oxides (COx), nitrogen oxides (NOx), sulfur dioxide $\left(\mathrm{SO}_{2}\right)$ and hydrocarbons, moreover their influence exceed the heat sources by double(2). In addition to transport, industrial products and other anthropogenic activities are leading to an increase in smog and toxic odors which classified as the main contributors in global warming, combined with unfavorable weather conditions (6). Several growing countries have a negative impact of urban road traffic at noise levels and air quality (12). At present, the continuous increase in the numbers of vehicles and ambient makes the scientific community focused on how to protect environment (19). Many researchers in the 21 st century try to generate new technologies which might help in improving the atmosphere (25). According to the latest reports, carbon monoxide (CO) occupied a major position among various gases deteriorating the air quality (5). Automobile emissions are responsible for more than $97 \%$ of $\mathrm{CO}$ in urban centers that need to justify the world concern about this affliction (5). CO is a by-product of the partial burning of organic compounds and reported as the main effluent from leaded fuel combustion (18). Approximately one-third of gas poisoning cases belong to direct exposure to carbon monoxide, due to its lack of taste, odor and color (22). In general, CO is heavier than air, thus can facilitate the rapid accumulation and atmospheric retention even in a well ventilated confined area (2). Occupational hazards assessment for taxi drivers, traffic policemen, operators at petrol filling stations and car wash employers revealed an association between high $\mathrm{CO}$ blood level and continuous contact with vehicle emissions (26). It becomes clear that fumes emitted from motor vehicles exhaust with their strong smelling as gas or vapor are responsible for highly percentage of accidental toxic gas poisoning (3). In addition, long period reaching to several weeks, is required to develop symptoms of $\mathrm{CO}$ poisoning to be noticed (17). Such side effects combined with high $\mathrm{COHb}$ levels that might be detected in more than $10 \%$ for these occupations (13).Hence, these facts ensure its relevance to many chronic diseases in this cohort of people. According to general traffic directorate index for year 2017 more than 2.1 million vehicles are found in Baghdad city with daily gasoline consumption reached to 7.2 million liters. All these events will exacerbate city roads, increase the congestion states and deteriorate air quality. Therefore, this study aimed to measure $\mathrm{CO}$ emitted from vehicle exhausters as an attempt to perform an index for this pollutant and given awareness from long-term exposure, due to future scenario proposed a current development of automobile number in Baghdad city.

\section{MATERIALS AND METHODS}

The samples were collected from parks located at Al- Jadyria campus during the year 2017. All car owners were informed about the aim of this study and their consent was obtained as study participants. The study was conducted on the first morning, the period that parking vehicle is the heaviest. The cars were classified according to engine capacity (size) which is divided into below 1.6 Liter (L) (1600 CC) (Cubic Centimeter) to up to $2.0 \mathrm{~L}$ (2000 CC). Seven different vehicles from each engine size were tested to cover all the possible models and origins. Both manual and automatic transmissions were represented in the samples. Samples were collected during emissions when the vehicles at an idle state (the period after starting and engine rotations (Rotation per Minute) (RPM) below 1000 (speed $0 \mathrm{Km} / \mathrm{h}$ ). The models ranged from (2008-2017) and the odometer (ODO) which mean the cruising distance $(\mathrm{Km})$ was also considered. The type of fuel was also included 
in the criteria selection, so the vehicles were divided into two groups according to the fuel (gasoline) they filled with: including premium leaded and leaded free gasoline (PLG and LFG respectively). Portable instrument model (Altair ${ }^{\circledR} 4 \mathrm{X}$ ) designated for measuring $\mathrm{CO}$ levels was used as the main device for vehicle exhaust emission testing. This gas detector is made by (MSA safety company), USA, with recent calibration. About $10 \mathrm{~min}$ was a stable period for the instrument to be put proximity to exhauster without any alteration in vehicle state (4).The same period was used to keep engine warming up (11). Several automotive brands were chosen due to their high distribution in Iraqi markets, including Toyota, Nissan, KIA, Hyundai, Chery, Geely, Samand, Peugeot, and Saipa. Before commencing the study, the instrument automatically zeros itself and routinely during data collecting. The zeroing was done by the measurement of ambient air away from exhauster that is believed to be free of significant levels of $\mathrm{CO}$ (4). In contrast, some information was gathered by questioner related with the last time in it the spark; engine oil and air filter had been replaced. Statistical analysis, data was analyzed and displayed using Graph Pad (v6) and significance was determined using twoway ANOVA test analysis, depending on data normalcy.

\section{RESULTS AND DISCUSSION}

The transportation system in developed nations means reached a balanced position between provides and need (20). Traffic density affected by the number of vehicles due to their direct relationship, particularly when new vehicles entering the transportation system (24). This continuous entrance reduced the spaces and increased the interference among vehicles, subsequently, the traffic flow would be changed, and the roads become full (24). These conditions cause a reduction in vehicles speed that warrants the detecting of exhaust emissions at idle position. As mentioned before, data were collected during (November and December 2017) and the collection was carried out in the early morning when the sunlight at a minimum and the presence of other pollutants can be ignored (5). The concentration of $\mathrm{CO}$ in the ambient was recorded about $5 \mathrm{ppm}$ and the air temperature was also documented which ranged between (16-26) ${ }^{\circ} \mathrm{C}$ throughout the study. Daily weather condition was reported with an assistance of the national metrological service. The vehicles were classified into two groups, the first elucidated $\mathrm{CO}$ concentrations emitted from those filled with premium leaded fuel whereas the other for those filled with leaded free, and both are at idle state. The results showed a high CO level for PLG reached to a maximum which recorded (939 ppm) whereas the lowest is (206.111ppm) at 1.8 and $2.0 \mathrm{~L}$ engine groups respectively with odometer rate (13000-120000) Km. In contrast, a decline in CO levels (table 1)for vehicles filled with LFG. The maximum level reached to (21.5714 ppm) while the lowest showed an interesting level (9.5714 ppm) at 1.6 and $1.8 \mathrm{~L}$ respectively with odometer rate (15000100000) $\mathrm{Km}$ as compared with the first group.

Table 1.Carbon monoxide concentrations $(\mathbf{p p m})$ represented as (mean \pm SD) for vehicles filled with leaded and free leaded fuel

\begin{tabular}{|c|c|c|c|}
\hline \multirow{2}{*}{ Engine size / Liter } & \multicolumn{2}{|c|}{ CO emissions concentration (ppm) } & \multirow{2}{*}{$\begin{array}{c}\text { Mean } \\
\pm \\
\text { SD } \\
\end{array}$} \\
\hline & \multirow{2}{*}{$\begin{array}{c}\text { PLG } \\
\text { 630.714 }\end{array}$} & \multirow{2}{*}{$\begin{array}{c}\text { LFG } \\
15.2857\end{array}$} & \\
\hline Ioss than < 1 6 & & & mean \\
\hline Less tilant 1.0 & 132.665 & 3.3926 & standard deviation \\
\hline 16 & 814.571 & 21.5714 & mean \\
\hline & 252.289 & 7.71479 & standard deviation \\
\hline 18 & 939 & 9.5714 & mean \\
\hline & 305.075 & 2.64447 & standard deviation \\
\hline & 206.111 & 19.7143 & mean \\
\hline 2.0 & 43.6375 & 7.41849 & standard deviation \\
\hline More than $>2.0$ & $\begin{array}{c}667 \\
235.047\end{array}$ & $\begin{array}{l}20.8571 \\
3.64122\end{array}$ & $\begin{array}{l}\text { mean } \\
\text { standard deviation }\end{array}$ \\
\hline
\end{tabular}




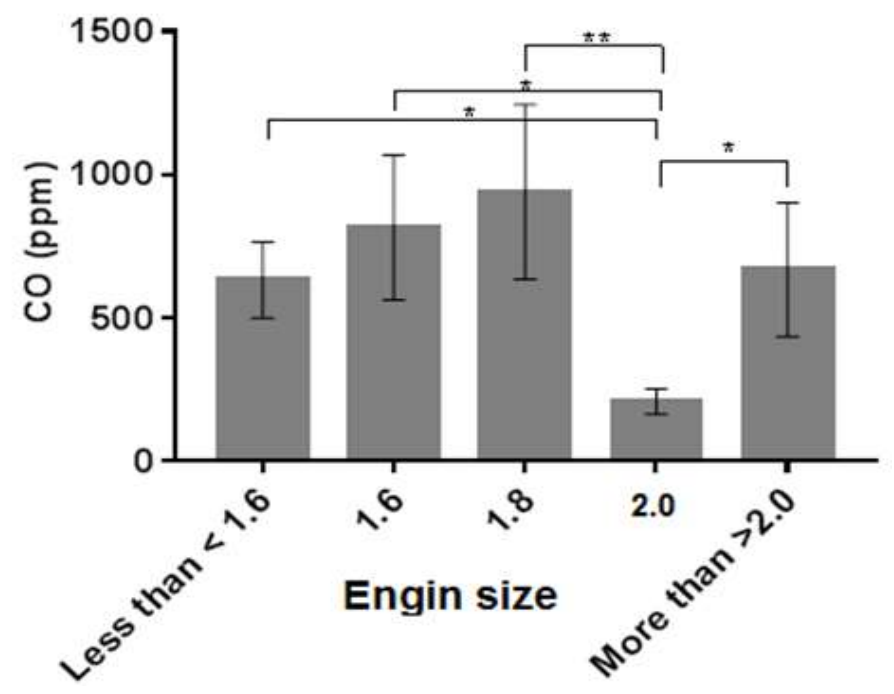

Figure 1.Mean concentration (ppm) of CO emitted from vehicles filled with PLG *(p $\leq 0.05)$, ** $(\mathbf{p} \leq \mathbf{0 . 0 1})$

Significant differences $(\mathrm{p} \leq 0.05)$ are scored driving behavior and the duration of both cold among engines with size $<1.6,1.6,2.0$ and $>2.0 \mathrm{~L}$. While, a high significance variation $(\mathrm{p} \leq 0.01)$ was found between 1.8 and $2.0 \mathrm{~L}$. However, the measurement of the emissions from vehicles at idle position (zero speed and zero acceleration) may be different than those measured during the acceleration. Previous studies suggested that $\mathrm{CO}$ emissions during idle are lower than acceleration. The explanation of this situation related to fact that more quantity of fuel had been injected at acceleration which resulting in high fuel combustion as well as more exhaust products (11).Despite this fact, the researchers instead postulated that how those kilometers are traveled is more necessary than the period of the trip (4).Many factors affect the engine start even to high enrichment operation that reflect adversely on total emissions regardless of vehicles cruising distance, model and origin (16). The using of portable instrument represented an active and relatively low-cost method like that developed by Vojtisek- Lom, and Cobb (23), when they used equipment aimed to assess shuttle bus emissions at Pittsburgh University. Therefore it's important to develop and deploy procedure for obtaining on-road quantity through the actual users to enhance prospective management of air quality and identified the hot spots in order to improve traffic signal coordination and timing in large cities (4). Figure 2 indicated significance of variation $(\mathrm{p}<0.05)$ among different engines size except of group $<1.6 \mathrm{~L}$. functions for example, high acceleration,

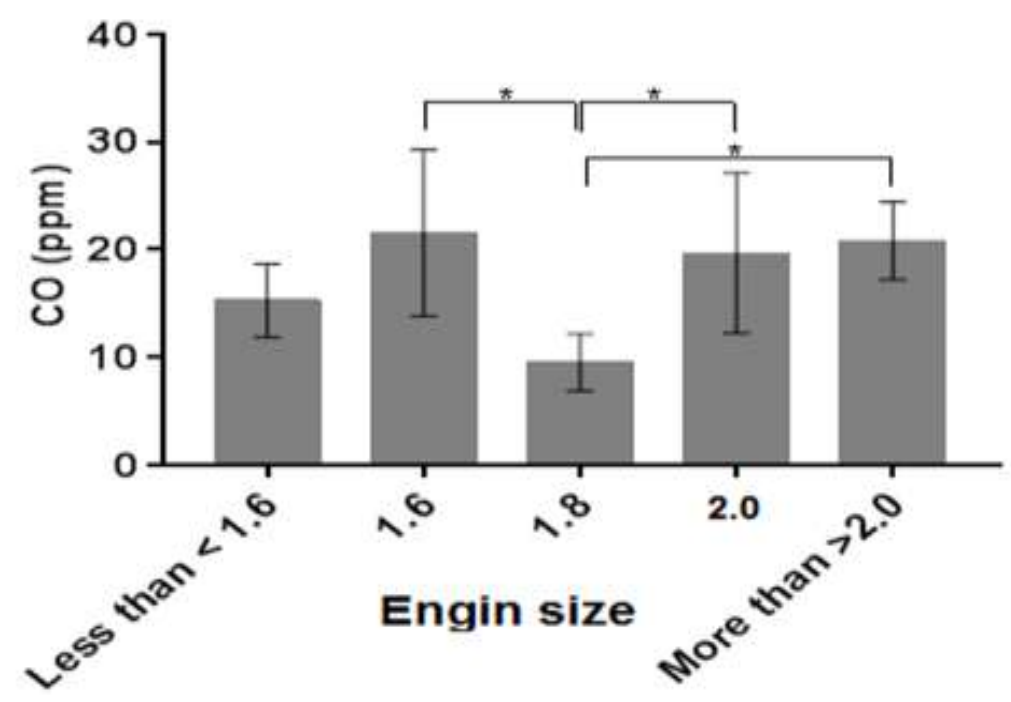

Figure 2. Mean concentration (ppm) CO emitted from vehicles filled with $\mathrm{LFG} *(\mathbf{p} \leq \mathbf{0 . 0 5})$ 
A majority of modern vehicles equipped with catalyst; after only one tank of leaded gasoline a rapid decline in its performance will occur steadily. According to Michael(15) EPA performed an experiment using five vehicles provided with catalytic converter, each vehicle refueled ten times with gasoline contain 0.28 $\mathrm{g} / \mathrm{L}$ of lead, the result revealed that $\mathrm{CO}$ emissions were nearly three times more than the original levels. Figure 3 showed no significant differences are observed among vehicles with engine size below 1.6 and $2.0 \mathrm{~L}$ respectively. The analysis of variance illustrated significant differences $(\mathrm{p} \leq 0.05)$ for vehicle groups (1.6 and more than 2.0) L. Similarly, statistical analysis indicated a significance of variance $(\mathrm{p} \leq 0.01)$ within group $1.8 \mathrm{~L}$.

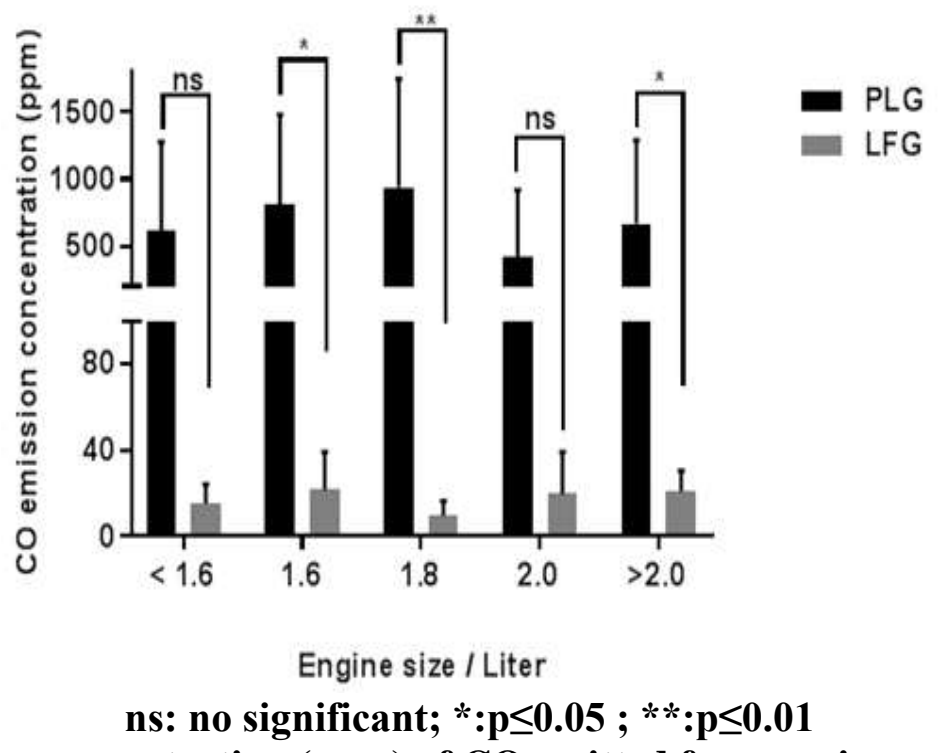

Figure 3.Mean concentration (ppm) of $\mathrm{CO}$ emitted from various engine groups

Hajderi and Vyshka(7) analyzed the combustion process; they found that higher temperature is generated at loaded mode as compared with idle (no loaded); due to this variance the $\mathrm{CO}$ emissions at idle state would be lower. This is consistent with study of Kadhim and Adhas (11), who noticed a high gases rate at $50^{\circ} \mathrm{C}$ as compare with 45 and $40^{\circ} \mathrm{C}$, this due to direct correlation between combustion temperature and gas concentration in exhauster. Continuous renewable of air filter provided the mixture air / fuel with sufficient amount of oxygen ,therefore improper rate for burning of fuel mean that oxygen is insufficient to oxidize all carbon and it will result a high value of noxious gases (8). Collectively, these informations can be used to control engine performance which is affected by many criteria such as type of fuel, spark ignition, and purity of air filter. Recently, the government efforts are focused on reducing the use of tetramethyl and tetraethyl lead as an anti-knocked. Instead one ring aromatic hydrocarbons were added to maintain this purpose in LFG (9). The results obtained from this replacement indicated a high concentration of poly aromatic hydrocarbons
(PAH) which classified as probable or possible human carcinogens especially the risk of leukemia (10). Unavailable techniques necessary to examine these compounds represent an alarm against LFG to be used with caution especially it's imported from other countries, which don't adopt the same environmental protection standards. The lead industry argument is about benzene and aromatics incurred by old vehicles had not equipped with catalyst that destroy 90 to 95 percent of emissions in the exhaust stream (14). Overall, evaluation the pipe emissions from internal combustion engine with fuel injection system is a difficult task facing by contradictory legislation world around and required a sophisticated work to mange reliable measurements (1). More over the upgrading octane value by gasoline oxygenation within refining processes can produce final product with considerable reduction of harmful $\mathrm{CO}$ emissions (14). In general, the challenge of improving the air quality conflicted with increased number of vehicles in our country, consecutive checkpoints scattered on roads and bad behaviors of drivers are the main contributors 
to total emissions. In recent years a concept developed in the world wide about how to deploy or at least control burned engine emissions. In this study portable instrument is used for measuring the emissions of gases from vehicles exhaust pipe in order to detect the amount of harmful gases. The analysis of gases at idle position it seems that vehicles filled with PLG greatly contributed in CO levels as compare with those filled with LFG. Consequently, this study represented an attempt to investigate the accurate levels in vehicles with various engine sizes at no loaded mode and given awareness to its influence on public health. Therefore, further studies are needed for exact measuring and other loaded and accelerated modes should be incorporated.

\section{REFERENCES}

1. Broatch, A.; J. M. Luja'n; S. R. Ruizand P. Olmeda. 2008. Measurement of hydrocarbon and carbon monoxide emissions during the starting of automotive di diesel engines.

International Journal of Automotive

Technology.9 (2):129-140

2. Centers for Diseases Control and Prevention Carbon Monoxide hazards from Small Gasoline Gower Engines and Tools. CDCP. 2013.NIOSH. pp: 96-118a

3. Cobb, N. and R.A. Etzel. 1991. Unintentional carbon monoxide-related deaths in United States, 1979 through 1988.J.A.M.A.266:659-663

4. Frey, H.C.; N. M. Rouphail; A. Unal and D. Colyar. 2001. Measurement of On-Road Tail Pipe $\mathrm{CO}, \mathrm{NO}$, and Hydrocarbon Emissions Using Portable Instrument. Annual Meeting of the Air and Waste Management Association, pp. $1-20$

5. Garcia, L.F.A.; S.M. Correa; R. Penteado; L. C. Daemme; L. V. Gatti and D. S. Alvim. 2013. Measurement of emissions from motorcycles and modeling its impact on air quality.J.Braz.Chem.Soc.24 (3):1-12

6. Hajderi, A.2010. On the reduction of environmental pollution caused by automobile emissions. Journal of studies on economics and society. 2(2):113-118

7. Hajderi, A. and E.Vyshka. 2014. The measurement accuracy of vehicle pollutant gases. Interdisplinary Journal of Research and Development. 1(1):81-84
8.

Halderman,

D.J.2012.Automotive

Technology Principles, Diagnosis and Service, pp: 918-945

9. Hsiao-Hsuan, M.; L. Wen-Jhy; T. Perng-Jy and C. Chung-Ban. 2001. A comparison on the emission of polycyclic aromatic hydrocarbons and their corresponding carcinogenic potencies from a vehicle engine using leaded and leaded -free gasoline. Environmental Health Perspective. 109(12):1285-1290

10. International Agency for Research on Cancer (IARC).1987. Over all evaluations of carcinogenicity: an updating of IARC monographs volume 1-42. IARC Monogr. Risks Hum. Suppl.7:1-440

11. Kadhim, N.S. and S. M. Adhas. 2015. Study performance and emission of diesel engine fueled with different diesel fuel temperature. The Iraqi Journal of Agricultural Sciences.46 (5):876-883.

12. Kumar, P.; M. Ketzel; S. Vardoulakis; L. Pirjola and R. Britter. 2011. Dynamic and dispersion modeling of nanoparticles from road traffic in the urban atmospheric environment. Journal of Aerosol Science.42 (9):580-603

13. La Fauci, G.; G. Weister; I.P. Steiner and I. Shavit. 2012. Carbon monoxide poisoning in narghile (water pipe) tobacco smokers.C.J.E.M.14:57-59

14. Manufacturers of Emission Controls Association MECA. 1998. The Case for Banning Lead in Gasoline. Washington, DC, pp: 1-35

15. Michael, R.B. 2013.The Emission Effects of Misfueling Five 1981-82 Model Year Automobiles with 10 Continuous tankfuls of Leaded Gasoline. U.S. Environmental Protection Agency, Office of mobile Sources, AnnArbor, MI, pp: 1-26

16. Modeling Mobile-Source Emissions (MMSE).2000. National Academy Press; National Research Council; Washington, D.C. pp.238

17. Nelson, L.S. and R.S. Hoffman. 2010. Carbon Monoxide. Rosen's Emergency Medicine: Concept and Clinical Practice. Marx J, Hockberger R, Walls R (eds), $7^{\text {th }}$ ed. Philadelphia, MOSBY Elsevier .PP : 20372038 
18. Prockop, LD. and RI.Chichkova.2007. Carbon monoxide intoxication. J. Neurol .Sci.262:122-130

19. Rhys-Tyler, G.A.; W. Legassick and M.C. Bell. 2011. The significance of vehicle emissions standards for levels of exhaust pollution from light vehicles in an urban area. Atmospheric Environment. 45 (19) :32863293

20. Siebel, F.; W. Mauser; S. Moutari and M. Rascle. 2009. Balance vehicular traffic at bottleneck. Mathematical and Computer Modelling.49 (3-4):689-702

21. Topacoglu, H.; Katsakoglou and A. Ipekci. 2014. Effect of exhaust emissions on carbon monoxide levels in employees working at indoor car wash facilities. Quarterly Medical Journal.18 (1):37-39

22. Van Meter, K.W.2010.Carbon Monoxide Poising. Tintinalli JE, Kelen GD, Stapczynski JS (eds), Emergency Medicine A
Comprehensive Study Guide, $6^{\text {th }}$ ed. McGrawHill. New York, NY, pp: 1238-1241

23. Vojtisek-Lom, M. and J.T. Cobb. 1997. Vehicle Mass Emissions Measurement Using a portable 5-gas Exhaust Analyzer and Engine Computer Data, Proceeding: Emission Inventory, Planning for Future. Air and waste Management Association. Pittsburgh, PA, pp: 1-15

24. Xue, H.; S. Jiang andB. Liang. 2013. A study on the model traffic flow and vehicle exhaust emission, pp: 1-6

25. Yi, K.; L.Z. Wang; B.X. Qi; L.M. Zhang and S. Lei. 2001. Investigation and analysis of motor vehicle exhaust emission in cities. Energy Conversion and Application. 1(2):250253

26. Yilmaz, A. and G. Guvendik. 2003. The blood carboxyhemoglobin levels of individuals occupationally exposed to exhaust pollution.J.Fac .Pharm. Ankara. 32:213-219. 